\title{
Refleksje po lekturze książki o Ruth Bryan Owen, czyli słów kilka o pierwszej Amerykance w randze posła i jej służbie dyplomatycznej
}

\author{
Rudd Brown, Ruth Bryan Owen. Congresswoman and Diplo- \\ mat. An Intimate Portrait, Pasadena 2014, ss. 231
}

Przez blisko 150 lat Amerykanki nie sprawowały żadnych funkcji w dyplomacji i chyba nie miały, oprócz kilku odnotowanych przez historyków przypadków, takich aspiracji. Pracowały jedynie jako sekretarki, stenotypistki, czy telefonistki. Zresztą, dyplomacja była nie tylko domeną mężczyzn, ale w gruncie rzeczy pozostawała nadal elitarną profesją, pilnie strzeżoną i zastrzeżoną dla wąskiego grona wtajemniczonych, klubu dżentelmenów. Trafiali do niej zazwyczaj absolwenci Ivy League, biznesmeni i ich synowie oraz osoby z nadania politycznego, zgodnie z obowiązującym tzw. systemem łupów politycznych (spoils system).

W latach dwudziestych XX wieku - w związku z ratyfikowaną 20. poprawką do Konstytucji nadającą prawa wyborcze kobietom, po raz pierwszy Amerykanki zaczęły ubiegać się również o pracę w dyplomacji. Wywołało to niemałą konsternację i zamieszanie w elitach rządowych, a zwłaszcza wśród dyplomatów i tzw. profesjonalistów (czyli Foreign Service Officers - FSOs), których kolejne etapy karier były związane z systemem merytorycznych promocji. Fakt, że kilka odważnych dziewcząt starało się o pracę i to bynajmniej nie w charakterze sekretarek, lecz profesjonalnych urzędniczek, wywołał niemałe zamieszanie w kręgach Departamentu Stanu. Formalnie nie można było im zabronić zdawania egzaminów ani aplikowania do służby konsularnej, czy dyplomatycznej (a po wprowadzeniu Rogers Act z 1924 roku scentralizowanej i zunifikowanej służby zagranicznej), ale podjęto szereg dosyć skutecznych prób, by zahamować ten - jak to nazywano - „,niebezpieczny”, czy wręcz „,radykalny” eksperyment ${ }^{1}$.

1 Więcej na ten temat: A.M. Morin, Her Excellency. An Oral History of American Women Ambassadors, New York 1995; H.L. Calkin, Women in the Department of State: Their Role in 
W rezultacie jedynie kilka pań - po zdaniu trudnych egzaminów - podjęło pracę na placówkach zagranicznych USA, co prawda na podrzędnych stanowiskach (zazwyczaj wicekonsula lub trzeciego sekretarza poselstwa). Niełatwe warunki pracy $\mathrm{w}$ obcym środowisku, niechęć męskiego otoczenia i brak awansu zniechęcał nawet te najbardziej pozytywnie motywowane, profesjonalne i świetnie przygotowane do takiej pracy, jak Lucille Atcherson, czy Pattie H. Field. Spośród kobiet, które zdały stosowne egzaminy, jedynie sześć w latach dwudziestych XX wieku podjęło pracę w służbie zagranicznej, a do 1930 już tylko dwie z nich nadal w niej pozostały. Były to Constance Harvey i Frances Elizabeth Willys, z czasem awansujące, już po II wojnie światowej - zgodnie z systemem merytorycznych awansów - do wyższych stanowisk ${ }^{2}$. Były to wszak sporadyczne wyjątki.

Pierwszą Amerykanką, która samodzielnie kierowała placówką dyplomatyczną USA, była Ruth Bryan Owen, wysłana w 1933 roku przez Franklina Delano Roosevelta do Danii. Była to typowa nominacja polityczna za pomoc w kampanii wyborczej 1932 roku. Fakt, że była pierwszą Amerykanką w randze posła, dawał pewne wrażenie (a w każdym bądź razie tak to nieraz interpretowano), że był to wyraz uznania nie tylko dla niej, ale w ogóle dla kobiecych aktywistek w Partii Demokratycznej. Przede wszystkim był to jednak rezultat zabiegów Eleanor Roosevelt i grona jej przyjaciólek (,women's network”), które usilnie starały się (czasem przecież skutecznie) o wprowadzenie kobiet na różne stanowiska państwowe³.

Ruth Bryan urodziła się 2 października 1885 roku w Jacksonville (Illinois). Była córką Williama Jenningsa Bryana, znanego i wpływowego polityka Partii Demokratycznej, uzdolnionego mówcy, trzykrotnego pretendenta do prezydentury (1896, 1900 i 1908), sekretarza stanu w administracji Thomasa Woodrow Wilsona i przyjaciela Cordella Hulla. Była najstarszą córką Bryanów, którzy zadbali o jej dobre wykształcenie. Po ojcu odziedziczyła niezwykły głos i zdolności oratorskie, co okazało się bardzo przydatne w jej późniejszej karierze publicznej. Jej bardzo ciekawa biografia, burzliwe, bogate i niezwykle barwne życie nie znalazło dotychczas pełniejszego opracowania ${ }^{4}$.

American Foreign Affairs, Washington 1978; A. Mania, Department of State 1789-1939. Pierwsze 150 lat udziału w polityce zagranicznej USA, Kraków 2011, s. 220-222.

2 Szerzej o tym mówiłam na konferencji w Białymstoku 23 maja 2015 w referacie Reformatorki i pionierki: Amerykanki w polityce i dyplomacji Stanów Zjednoczonych w okresie międzywojennym.

3 E.S. M. Born for Liberty. A History of Women in America, New York 1989, s. 205.

4 Warto wszak odnotować kilka pozycji na jej temat, m.in. S.P. Wickers, Ruth Bryan Owen: Florida's first U.S. Congresswoman and America's first Ambassador to Denmark, Tallahassee, FL 2009 oraz rozdział Ruth Bryan Owen: Florida's first congresswoman w pracy W.E. Lynne, Remarkable Florida women, Guildford, CT 2010, a także rozdział VI o identycznym tytule w pracy J. Freeeman We will be heard: women's struggles for political power in the United States, Lanham, Md 2008. 
Z tym większym zainteresowaniem sięgnęłam po książkę napisaną przez Rudd Brown, najmłodszą jej latorośl z drugiego małżeństwa. Córka napisała ją wiele lat po śmierci matki, która zmarła w Kopenhadze w lipcu 1954 roku. Materiały do niej gromadziła przez kilkadziesiąt lat, przeprowadzając wywiady z rodziną i przyjaciółmi, zbierając wycinki prasowe, uzupełniając domową ikonografię.

W niniejszej pracy Ruth Bryan Owen Rohde ukazana została w bardzo osobistej perspektywie (a więc i niezwykle subiektywnej), w przeważającej mierze na bazie własnych wspomnień oraz bliskich i przyjaciół, choć autorka dodaje, że czasem sięgała do źródeł historycznych (s. 54). Książka z pewnością nie pretenduje do biografii, lecz raczej jest luźną narracją wspomnieniową o matce (niekoniecznie dobrze ocenianą przez własne dzieci) oraz zaangażowanej aktywistce i kobiecie niezwykłej, brylującej na salonach i podziwianej w świecie polityki. Mimo oczywistego subiektywizmu, a także drobnych nieścisłości, praca zasługuje na uwagę i uważną lekturę. Dostarcza sporo nowych informacji, zważywszy że odsłania nieraz nieznane szczegóły z życia bohaterki, jej relacji z czwórką dzieci, jak też przybliża klimat ówczesnych wydarzeń nie tylko w życiu rodzinnym, ale i publicznym Ruth Bryan Owen. Wspomina jej rozliczne krajowe odczyty, które - z perspektywy dzieci i ciągłej rozłąki z matką angażującą się w „ważne sprawy” - były ich prawdziwą udręką, dla niej samej były natomiast wydarzeniami, którymi się pasjonowała i dzieliła te radości oraz sukcesy w gronie przyjaciół. Dopiero z czasem Rudd Brown zauważyła i poniekąd doceniła, że wyjazdy odczytowe matki, cieszące się zainteresowaniem rodaków i dużą popularnością, przynosiły też jej spory dochód, a więc pozwalały zabezpieczyć byt materialny ich rodziny (s. 71).

Ruth Bryan wychodziła za mąż trzykrotnie. Najpierw za malarza portrecistę Williama Homera Leavitta, z którym miała dwójkę dzieci (Johna i Kitty), i z którym po 7 latach rozwiodła się w 1909 roku. Niedługo potem, w 1910 roku wyszła za mąż z „wielkiej miłości” za brytyjskiego oficera Reginalda Oltham Owena. $\mathrm{Z}$ tego związku urodziło się także dwoje dzieci - syn Bryan i córka Rudd, autorka niniejszej książki, która przyszła na świat w sierpniu 1920 roku (s. 58). W 1936 roku, owdowiała od lat Ruth Bryan Owen wyszła kolejny raz za mąż za Borge Rohde, oficera Gwardii Królewskiej Danii.

W latach dwudziestych Ruth Bryan Owen wiele podróżowała, próbowała robić filmy, a następnie - mimo licznych obowiązków rodzinnych i opieki nad schorowanym mężem - zainteresowała się działalnością polityczną. W 1926 roku nieskutecznie zabiegała o wejście do Izby Reprezentantów jako przedstawicielka Florydy, a w dwa lata potem, w 1928 roku - już po śmierci drugiego męża (zmarłego w grudniu 1927 roku), jako wdowa i matka ,gromadki dzieci” jak czasem pisano w prasie - ponowiła próbę i wygrała wybory. Jej republikański rywal, który z nią przegrał, wniósł do Kongresu zastrzeżenia w sprawie jej nieaktualnego obywatelstwa. Wychodząc za mąż za Brytyjczyka, utra- 
ciła ona obywatelstwo amerykańskie, choć potem w 1925 roku złożyła prośbę o przywrócenie jej obywatelstwa USA (zgodnie z tzw. Cable Act z 1922 roku) ${ }^{5}$. Nie spełniała wszak, na co wskazywał rywal, wymogu konstytucyjnego w przypadku stanowisk wybieralnych, a więc co najmniej 7 lat bycia obywatelem USA. Ruth Bryan Owen podjęła walkę o uznanie jej obywatelstwa amerykańskiego (bo je wcześniej miała i ponownie je uzyskała), wskazując, że była to jawna dyskryminacja kobiet. Jak argumentowała, podobne przepisy małżeńskie nie dotyczyły mężczyzn, ponieważ żaden Amerykanin nie stracił obywatelstwa USA z powodu małżeństwa $\mathrm{z}$ cudzoziemką. W rezultacie, po burzliwych dyskusjach Komitet do spraw Wyborów uznał jej amerykańskie obywatelstwo, a zatem i możliwość pełnienia przez nią obowiązków w Kongresie (s. 89-94). Dyskusje i kontrowersje wokół jej obywatelstwa wpłyną w przyszłości na zmianę regulacji w kwestii małżeństw Amerykanek z cudzoziemcami, także pochodzenia azjatyckiego ${ }^{6}$.

Ruth Bryan Owen była pierwszą przedstawicielką Florydy i jedną z sześciu wówczas kobiet w Izbie Reprezentantów oraz pierwszą kobietą, członkinią Komisji Spraw Zagranicznych w Izbie Reprezentantów. Zasiadała w Kongresie przez dwie kadencje (4 marca 1929 - 3 marca 1933), poznając ludzi i sprawy oraz zdobywając doświadczenie, które okazało się niezwykle przydatne do późniejszej pracy dyplomatycznej. Angażowała się w promowanie kobiet w działalności publicznej i wspierała równouprawnienie. Była jedną z aktywniejszych obrończyń idei parków narodowych, m.in. Everglades na Florydzie, choć dziś raczej się o tym nie pamięta.

Ruth Bryan Owen, mimo błyskotliwej kariery w Izbie Reprezentantów, kolejne wybory w 1932 roku jednak przegrała, najprawdopodobniej z powodu stosunku do prohibicji, której była konsekwentną zwolenniczką. Z tym większą determinacją zabiegała o poparcie przez możnych przyjaciół jej kandydatury na stanowisko w administracji zwycięskiej ekipy Franklina D. Roosevelta. Ponoć to ona miała być ministrem pracy, a przynajmniej na to liczyła, jak twierdzi córka, a stanowisko to otrzymała Frances Perkins, pierwsza kobieta w amerykańskim rządzie (s. 123).

Córka potem napisze, że matka była „genialną celebrytką” w czasach, kiedy samo pojęcie dopiero wchodziło w obieg. Była osobą błyskotliwą, niezwykle to-

522 września 1922 roku Kongres przyjął ustawę (Married Women's Act, znaną powszechnie - od nazwiska jej inicjatora kongresmana z Ohio, Johna L. Cable - jako Cable Act), wedle której każda Amerykanka miała prawo do własnego obywatelstwa, a więc wychodząc za mąż za obcokrajowca nie traciła obywatelstwa amerykańskiego. Zgodnie z wcześniejszą ustawą imigracyjną z 1907 roku kobieta przyjmowała obywatelstwo męża. M. L. Smith, „Any Woman who is now or may hereafter be merried...". Women and Naturalization, ca 1802-1940 www.archives.gov/publications/prologue/ 1998/summer/women-and-naturalization-1.html, [data dostępu: 06.07.2015].

6 M. Mabie Gardner, The Qualities of a Citizen: Women, Immigration, and Citizenship, 1870 -1965 , Princeton 2005, s. 14. 
warzyską i medialną, co umiała zręcznie wykorzystywać w kontaktach z ludźmi. Wykazywała profesjonalizm w sprawach, którymi się zajmowała i odwagę w konsekwentnym głoszeniu poglądów i obronie prezentowanych przekonań czy racji. Ale w jej zapracowanym i zaangażowanym życiu publicznym rodzina - jak pisze Rudd Brown - schodziła na dalszy plan. Dzieciom jednak chciała i starała się zabezpieczyć dobrą edukację i wprowadzać w świat, w którym funkcjonowała. W 1930 roku Ruth Bryan Owen z dziećmi i przyjaciółmi zwiedzała Stany Zjednoczone, przemieszczając się od wschodniego wybrzeża do Yellowstone National Park, a rok później zorganizowała wyprawę do Europy. Córka pisze, że choć wówczas nie wiedziała dlaczego matka zabrała ich w tak daleką podróż, w tym także do Kopenhagi, ale dwa lata potem, kiedy tam wracała do pracy dyplomatycznej, zaczęła te fakty łączyć i sądzić, że może to nie było przypadkowe (s. 117, 123).

Sympatycznie, choć zdawkowo, wspomina wówczas 12-letnia córka, wieści prasowe, że matce powierzone zostanie jakieś ważne stanowisko w dyplomacji. Informacje o jej spotkaniu w poselstwie duńskim w Waszyngtonie wiosną 1933 roku i pogłoski prasowe oraz komentarze znajomych o ewentualnej misji dyplomatycznej matki przyjmowała tyleż z radością, co i obawami, bo nie bardzo wiedziała, co to miało znaczyć i jak miało wpłynąć na życie rodziny. Od najbliższego otoczenia starała się dowiedzieć, jaką pracę wykonuje poseł (,,minister" w języku angielskim to może być też pastor) i dlaczego matka nie będzie ambasadorem. Ten ostatni wyraz był jej bardziej znany i rozpoznawalny.... Ale i Rudd częściowo udzieliła się radość i entuzjazm matki, związany z wyjazdem do Danii i świadomością, że zapowiadał się nowy i ciekawy etap w życiu ich rodziny (s. 117-125).

Na uroczystym obiedzie, wydanym na cześć nowej Pani Poseł 9 maja 1933 roku w Nowym Jorku w Hotelu Waldorf, brali udział przedstawiciele establishmentu, przyjaciele i rodzina. Świętowano wielki sukces bohaterki tego dnia, jak i w ogóle sukces grona zaprzyjaźnionych kobiet z kręgu First Lady, która przemawiając, nie ukrywała wielkiej radości i satysfakcji z powodu nominacji Ruth Bryan Owen. Głos zabierała też powieściopisarka Fannie Hurst i słynna pilotka Amelia Earhart oraz badacz Islandii Vilhjalmur Stefansson.

Przed wyjazdem na placówkę do Kopenhagi Pani Poseł gościła w Białym Domu i w trakcie krótkiej rozmowy z Rooseveltem otrzymała stosowne instrukcje. To niezwykłe spotkanie z Prezydentem, towarzysząca jej wówczas córka opisała tak: „Wiedziałam, że obcuję z Wielkością i kompletnie zaniemówiłam, z wyjątkiem jednego nieśmiałego słowa «świetnie», wypowiedzianego w odpowiedzi na zapytanie Roosevelta, jak się mam" (s. 128).

Niedługo potem Ruth Bryan Owen, wraz z dziećmi i służbą, udała się statkiem w podróż do Europy. Listy uwierzytelniające złożyła 23 maja 1933 roku i była niezwykle ciepło przyjmowana przez gospodarzy. Prowadziła dom otwarty, chętnie goszcząc Duńczyków i Amerykanów oraz przedstawicieli korpusu dyplo- 
matycznego w Kopenhadze. Konsekwentnie uczyła się też duńskiego, przywiązując do tego pewną wagę, a może chcąc się wyróżnić, że jest jedyną dyplomatką, która zadała sobie taki trud. Faktem było, jak pisze córka, że w niespełna pół roku poznała użyteczne zwroty i pewien zakres słów, by w kilku zdaniach przemawiać do gospodarzy w ich ojczystym języku, dzięki czemu szybko zaskarbiła sobie ich sympatię. Jak podkreśla Rudd, matka lubiła swoją pracę dyplomatyczną, czuła się ważna i była „przede wszystkim Madame Poseł”. W zasadzie o tym „nigdy nie zapominała i chlubiła się tym, że służba duńska zwracała się do niej «Wasza Ekscelencjo»" (s. 130).

Wzmiankuje zabawnie Rudd Brown o problemach protokolarnych, które matka napotykała na początku. Zaczęły się od potrzeby zapoznania się z etykietą dworską i właściwego stroju, w którym miała składać listy uwierzytelniające królowi. Chciała wypaść perfekcyjnie, ale ani ludzie z najbliższego jej otoczenia, ani personel amerykańskiego poselstwa nie potrafili udzielić jej należytych podpowiedzi czy instrukcji w tych kwestiach. Zwrócono się nawet do poselstwa amerykańskiego (autorka błędnie podaje, że do Sztokholmu, a chodziło o Oslo) z zapytaniem, jak była ubrana ambasador radziecka Aleksandra Kołłontaj, kiedy tam w 1923 składała listy uwierzytelniające.

Ruth Bryan Owen swoje obowiązki poselskie traktowała bardzo poważnie, czasem wyjeżdżała z Kopenhagi, by lepiej poznać ludzi i kraj swego urzędowania. Brała udział w licznych uroczystościach i ceremoniach, odwiedzała domy swoich duńskich przyjaciół, których przybywało, wygłaszała odczyty. Odbyła też podróż na Grenlandię. Chętnie pozowała dla mediów i fotografowała się z miejscowymi osobistościami, zwłaszcza z kręgów dworu królewskiego i innych. Zarzucała też Waszyngton raportami, apelując o zmniejszenie taryf celnych dla Danii, by ożywić wzajemną wymianę handlową, jak argumentowała. W raportach do Departamentu Stanu, a czasem też do Prezydenta, Ruth Bryan Owen rzeczowo informowała o sytuacji w kraju urzędowania i państwach skandynawskich oraz szerzej o napięciach europejskich. Była bystrą i dobrą obserwatorką. Szybko weszła w rytm pracy dyplomatycznej, rzeczowo wykonując powierzoną jej misję, choć nie wydaje się, że szczerze zadowalała ją ta placówka. Ponoć marzyła o znacznie bardziej prestiżowej - o placówce dyplomatycznej w Londynie. Nie znam źródeł, które by potwierdziły, iż taką ewentualność rozważano w Waszyngtonie. Zresztą należy pamiętać, że amerykańskie ambasady w Londynie, Paryżu, czy Berlinie uchodziły za ważne i prestiżowe, a więc i nie tak łatwo dostępne dla potencjalnych chętnych. Obsadzane były zazwyczaj z nadania politycznego osobami, które wniosły szczególnie duży wkład (głównie finansowy) w zwycięstwo wyborcze.

Jak po latach napisze córka, mimo iż matka lubiła ceremoniał i splendory, i była zadowolona $\mathrm{z}$ pracy dyplomatycznej w Kopenhadze, zdecydowała się „pójść za głosem serca, a nie rozumu”. Przerwała w ten sposób swoją błyskotliwą karierę, zamykając zarazem ważny etap publicznej aktywności. Ruth 
Bryan Owen postanowiła wyjść za mąż za wspomnianego już wcześniej kapitana Gwardii Królewskiej, znacznie od niej młodszego (co było pilnie strzeżoną tajemnicą), Borge Rohde. Ślub miał się odbyć w USA, choć szczegółów na temat tego wydarzenia długo nie zdradzano opinii publicznej. Wiadomo wszak było, że uroczystość została zorganizowana przez grupę przyjaciół z kręgu Eleanor Roosevelt (s. 137).

Ruth Bryan Owen przebywała w Kopenhadze do lata 1936 roku, po czym wróciła do kraju na swój własny ślub, który odbył się 13 lipca 1936 roku w kaplicy w Hyde Parku. Poślubiła kapitana Borge Rohde, a w ceremonii uczestniczył Prezydent Roosevelt z małżonką oraz grono przyjaciół panny młodej, co znalazło też odzew w mediach. Ceremonia ślubna została uwieczniona w krótkim filmie dokumentującym nie tyle samą uroczystość, co biorące w niej udział ważne osobistości publiczne z najbliższego kręgu Rooseveltów.

Małżeństwo dyplomatki z kapitanem Borge Rohde wywołało liczne spekulacje i niemałe kontrowersje. Stało się też swego rodzaju sensacją w kręgach dyplomatycznych, a dla Departamentu Stanu stworzyło też pewien kłopot. W roku wyborczym było to niekorzystne, zwłaszcza dla administracji Roosevelta i demokratów, obawiających się ,,jakiegoś skandalu” i negatywnego wydźwięku prasowego. Nawet życzliwi temu związkowi małżeńskiemu politycy widzieli ,problem lojalności" czy też niejasności protokolarnych. Jej sprawą interesował się brytyjski ambasador w Waszyngtonie, pytając Wilbura J. Carra, jak to było możliwe, że po zaślubieniu obywatela obcego kraju mogła pełnić obowiązki posła USA. Ten rozbrajająco szczerze, choć nie bez złośliwości, przyznał, że o ceremonii ślubnej pani Owen dowiedział się z prasy. Carr nie ukrywał zdumienia i oburzenia z powodu tego ,śmiesznego incydentu”, niekonsultowanego wcześniej z Departamentem Stanu. Podkreślił też, że - w zaistniałej sytuacji - uznał, że była to sprawa do załatwienia przez samego Prezydenta, który powołał Ruth Bryan Owen na stanowisko w Kopenhadze ${ }^{7}$.

Nie bardzo wiedziano, jak amerykańska dyplomatka, zamężna z Duńczykiem, byłym gwardzistą królewskim, miała bezkolizyjnie pełnić nadal obowiązki posła w Danii. W kuluarach rządowych plotkowano i spekulowano na ten temat. Jakiś oburzony Amerykanin pisał nawet w tej sprawie do sekretarza Prezydenta Jamesa A. Farleya pytając, dlaczego rząd toleruje taki „niestosowny” związek małżeński dyplomatki. W niewybrednych słowach i zjadliwie dodawał, że być może dla Ruth Bryan Owen jest to ,znakomity spektakl”, ale nie jest to już li tylko jej sprawa prywatna. Pani Poseł wychodząc za mąż za znacznie młodszego mężczyznę, obywatela innego kraju „ośmiesza” tym samym naród i mocarstwo, które reprezentuje [! - dop. H.P., s. 138-139].

7 Okólnik Carra w tej kontrowersyjnej sprawie z dnia 24 lipca 1936 r. (Library of Congress, Manuscript Division, Papers of Wilbur J. Carr, 1892-1942, Box 13). 
Ponoć były podejmowane jakieś próby, by zatrzymać Ruth Bryan Owen na placówce w Danii, ale Departament Stanu jakoby nie chciał robić wyjątku. Ostatecznie zatem oficjalnie zrezygnowała ona z pracy dyplomatycznej i zajęła się kampanią prezydencką 1936 roku. Małżeństwo Pani Poseł z Duńczykiem stanowiło pewien precedens $\mathrm{w}$ dyplomacji. Przypadek ten był pilnie studiowany w rozmaitych gremiach decyzyjnych i zapewne wpłynął na zarządzenie Prezydenta z 17 listopada 1936 roku, które miało regulować sprawy małżeństw służby zagranicznej z cudzoziemcami ${ }^{8}$. W zaistniałej sytuacji, ślub amerykańskiej dyplomatki z cudzoziemcem dostarczył dodatkowych argumentów zagorzałym przeciwnikom służby dyplomatycznej kobiet, a zwłaszcza powoływania ich na stanowiska kierownicze w zagranicznych placówkach.

Córka przez lata sądziła, że była to świadoma decyzja matki, która mając do wyboru albo pracę dyplomatyczną, albo małżeństwo i miłość, wybrała to drugie. I poniosła w związku z tym oczywiste konsekwencje, wynikające z ówczesnych przepisów. Jakież było jej zaskoczenie i pewnego rodzaju rozczarowanie, kiedy po latach poznała pewne kulisy tej odległej już wtedy historii. W 1972 roku, podczas którejś z kolei podróży do Kopenhagi, dowiedziała się od Anny Ostergaard, sekretarki poselstwa, że szanse na powrót Ruth Bryan Owen do Kopenhagi po zamążpójściu przekreślił nie Departament Stanu i amerykańskie regulacje, lecz... duńskie Ministerstwo Spraw Zagranicznych. Ponoć na dworze królewskim obawiano się kłopotliwych spraw ceremonialnych i protokolarnych, ponieważ nie wiedziano, gdzie w trakcie uroczystości państwowych miałby zasiadać małżonek amerykańskiej Pani Poseł, obywatel duński i były gwardzista królewski. To nie dla rodaków, ale Duńczyków, których tak polubiła, stała się ona persona non grata. I przynajmniej dobrze, że - jak pisze - matka się o tym nigdy nie dowiedziała (s. 165-166).

Prezydent Roosevelt również powołał inną kobietę - Florence („Daisy”) Jaffray Harriman, sufrażystkę, reformatorkę i działaczkę klubów kobiecych Partii Demokratycznej do kierowania poselstwem w Oslo, choć i ta nominacja była również polityczna. Niemałą w tym rolę odegrało także poparcie wspomnianej już wcześniej „women's network” i samej Eleanor Roosevelt, zabiegającej o jej nominację. Po uzyskaniu aprobaty jej kandydatury przez Senat, Prezydent przyjął Florence Harriman na audiencji. Rozmowę i lunch w Białym Domu wspominała bardzo sympatycznie, tym bardziej, że udzielone porady przez Roosevelta miały się niebawem przydać. Zgodnie z jego sugestią zatrzymała się na kilka dni w Paryżu i Londynie, by lepiej zapoznać się z sytuacją w Europie. Napisała potem,

8 W. Barnes, J. H. Morgan, op. cit., s. 219. Zgodnie z tym zarządzeniem urzędnik służby zagranicznej (we wcześniejszej praktyce był to zwykle mężczyzna), który chciał zawrzeć związek małżeński z obywatelem innego kraju, był zobowiązany do złożenia w tej kwestii prośby o takową zgodę do Departamentu Stanu. W praktyce oznaczało to jego rezygnację ze służby zagranicznej USA. 
że jej praca dyplomatyczna była łatwiejsza dzięki temu, że już Ruth Bryan, jako pierwsza kobieta poseł, cztery lata wcześniej przełamała niektóre bariery w Departamencie Stanu. Również pozytywna ocena jej pracy na placówce w Kopenhadze ułatwiła w znacznym stopniu pracę dyplomatyczną Harriman w Oslo, nie była bowiem ,,pierwszą”, a jej poprzedniczka przetarła ten trudny szlak dla kobiet w dyplomacji9.

Wart podkreślenia jest fakt, że pierwsze amerykańskie dyplomatki akredytowane były w państwach skandynawskich (podobnie, jak i radziecka ambasador - Aleksandra Kołłontaj). Ich praca, kompetencje i profesjonalizm spotkały się z wysoką oceną sekretarza Cordella Hulla i urzędników Departamentu Stanu, ale dostęp Amerykanek do służby zagranicznej przez wiele dekad był bardzo ograniczony. W całym okresie międzywojennym jedynie kilka Amerykanek podjęło pracę na niższych rangą stanowiskach w dyplomacji, jednak bez większych szans na szybki awans. W latach 1930-1937 tylko dwie kobiety, które przeszły stosowne procedury i zdały egzaminy, pozostały w służbie zagranicznej. Były to wspomniane wcześniej: Constance Harvey (pierwsza kobieta Konsul Generalny) i Frances E. Willis. Pozostałe cztery zrezygnowały. A siedem innych kobiet wyprowadzono dosłownie z Senatu przez specjalne poczynania ${ }^{10}$. I choć od lat trzydziestych XX wieku pojawiły się Amerykanki pracujące w dyplomacji, a nawet kierujące poselstwem (Ruth Bryan Owen, Florence Harriman), tak naprawdę szanse na objęcie tego rodzaju stanowisk przez kobiety były bardzo nikłe.

Ruth Bryan Owen, jako utalentowana mówczyni, wzięła udział w kampanii prezydenckiej Roosevelta jesienią 1936 roku, a potem wygłaszała odczyty i sporo pisała. Zafascynowana Danią opublikowała na jej temat kilka książek, m.in. dobrze przyjętą książkę dla dzieci ${ }^{11}$, popularyzującą problematykę skandynawską w USA. W kilka lat potem wydała dwie inne pozycje o podobnej tematyce ${ }^{12}$.

Od 1939 roku Ruth Bryan Owen wykładała w Monticello College i nadal chętnie wygłaszała odczyty. Brała udział w pracach rozmaitych organizacji kobiecych promując aktywniejszy udział kobiet w życiu politycznym. W czasie II wojny światowej przygotowała swoje przemyślenia na temat przyszłości ${ }^{13}$. Prezydent Roosevelt zaangażował ją w Departamencie Stanu do prac przygotowawczych nad Kartą Narodów Zjednoczonych, a Harry Truman w 1949 roku powołał ją jako delegatkę do Zgromadzenia Ogólnego ONZ. Ruth Bryan Owen

9 F. Harriman, Mission to the North, Philadelphia-New York 1941, s. 37-41; S. Ware, op. cit., s. 147.

10 A. M. Morin, op. cit., s. 9.

11 Denmark caravan, illustrated by Hedwig Collin, New York 1936.

12 Picture tales from Scandinavia, selected and retold by Ruth Bryan Owen; illustrations by Emma Brock, New York 1939 oraz Castle in the silver wood and other Scandinavian fairy tales; retold by Ruth Bryan Owen (Mrs. Borge Rohde), illustrated by Marc Simont, New York 1939.

13 Look Forward, Warrior, New York 1943. 
zmarła w Kopenhadze na atak serca 26 lipca 1954 roku podczas podróży do Danii, gdzie miała odebrać z rąk króla Fryderyka IX odznaczenie za zasługi dla rozwoju stosunków amerykańsko-duńskich. Tam też spoczęła na jednym z cmentarzy, oddzielona od bliskich oceanem (s. 185-186).

Omawiana książka przybliża postać kobiety niezwykłej i zasłużonej w walce Amerykanek o równouprawnienie i należne im miejsce w społeczeństwie, choć stosunkowo mało znanej czy też w zasadzie niedocenionej i zapomnianej. Publikacja jest też próbą osobistego „rozliczenia się” najmłodszej córki ze swoim dzieciństwem i miejscem matki w jej życiu. Jest zarazem hołdem złożonym tej niezwykłej i błyskotliwej kobiecie. Rudd Brown wiele lat po jej śmierci, już jako matka i zaangażowana działaczka, zrozumiała to lepiej i uwolniła się od „demonów przeszłości”, narosłych pretensji, nieporozumień i żalów do Ruth, jak ją konsekwentnie zwykła nazywać. Z perspektywy późniejszych lat i własnych doświadczeń w życiu rodzinnym i politycznym potrafiła dostrzec w matce też kogoś bliskiego, a nie tylko kobietę sukcesu, błyskotliwą, niezależną i podziwianą aktywistkę. I zapewne, o czym świadczy książka, po wielu latach lepiej ją rozumiała i chyba na nowo pokochała.

\section{Bibliografia}

\section{Źródła}

Brown R., Ruth Bryan Owen. Congresswoman and Diplomat. An Intimate Portrait, Pasadena 2014.

Castle in the silver wood and other Scandinavian fairy tales; retold by Ruth Bryan Owen (Mrs. Borge Rohde), illustrated by Marc Simont, New York 1939.

Library of Congress, Manuscript Division, Papers of Wilbur J. Carr, 1892-1942, Box 13.

Morin A. Miller, Her Excellency. An Oral History of American Women Ambassadors, New York 1995.

Harriman F., Mission to the North, Philadelphia-New York 1941.

Picture tales from Scandinavia, selected and retold by Ruth Bryan Owen; illustrations by Emma Brock, New York 1939.

Owen Ruth Bryan, Denmark caravan, illustrated by Hedwig Collin, New York 1936.

Owen Ruth Bryan, Look Forward, Warrior, New York 1943.

\section{Literatura}

Calkin Homer L., Women in the Department of State: Their Role in American Foreign Affairs, Washington 1978.

Evans Sarah M., Born for Liberty. A History of Women in America, New York 1989. 
Gardner M. Mabie, The Qualities of a Citizen: Women, Immigration, and Citizenship, 1870-1965, Princeton 2005.

Mania A., Department of State 1789-1939. Pierwsze 150 lat udziału w polityce zagranicznej USA, Kraków 2011.

Ruth Bryan Owen: Florida's first congresswoman, [w:] W. E. Lynne, Remarkable Florida women, Guildford, CT 2010.

Ruth Bryan Owen: Florida's first congresswoman, [w:] J. Freeeman, We will be heard: women's struggles for political power in the United States, Lanham, Md 2008.

Smith M. L., „Any Woman who is now or may hereafter be married...”. Women and Naturalization, ca 1802-1940, www.archives.gov/publications/prologue/1998/summer /women-and-naturalization-1.html, [dostęp: 06.07.2015].

Wickers S. P., Ruth Bryan Owen: Florida's first U.S. Congresswoman and America's first Ambassador to Denmark, Tallahassee, FL 2009. 